УДК 726(497.11)"15"

https://doi.org/10.18485/godisnjak.2020.15.9

Настасија 3. Перић*

Филолошки факултет

Универзитет у Београду, докторанд
Оригинални научни рад

Примљен: 15. 09. 2020.

Прихваћен: 10. 11. 2020.

\title{
КТИТОРСКО-НАДГРОБНИ НАТПИС ЧЕЛНИКА ВУГДРАГА ИЗ ХІV ВЕКА У ЦРКВИ СВЕТОГ ЈОВАНА КРСТИТЕЉА У ДИЋИМА
}

У овом раду анализираће се натпис на ктиторско-надгробној плочи челника Вугдрага из XIV века, у селу Дићи. Анализом слова и правописних одлика настојаћемо да укажемо на палеографске особености овог текста исклесаног у камену. Натпис ћемо одредити просторно и временски стављајући га у историјски контекст, у оквиру којег ће се отворити одређена питања и хипотезе везане за живот и смрт челника Вугдрага.

Кључне речи: некропола, челник Вугдраг, црква, Рудник, слово, плоча, XIV век.

\section{Просторно-временско одређење}

Године 1991. започето је археолошко истраживање Завода за заштиту споменика културе Ваљево на простору данашњег сеоског гробља у Дићима. Локалитет је носио топоним Манастирине (Манастирско). Том приликом пронађени су остаци средњовековне цркве са некрополом, као и праисторијски тумулус. Захваљујући архитектури грађевине, ктиторској плочи са натписом, утврђено је да се ради о цркви из XIV века, коју је ктитор, челник Вугдраг, подигао 1327. године. На основу пронађених

*gorskimis12@gmail.com 
новчића, керамике и начина сахрањивања, зна се да је некропола око цркве настајала у периоду од XIV до XVII века (Јеж 2001: 137). Сахрањивање се наставило од друге половине XIX века, па све до данас. Црква је рестаурирана и отворена за посетиоце, а посвећена је Светом Јовану Крститељу.

Локалитет поменуте средњовековне цркве са некрополом налази се у селу Дићи, осам километара од Љига, а тридесет километара од планине Рудник. Лежи на левој страни магистралног пута (Ибарска магистрала), идући од Љига ка Горњем Милановцу. Од села Гукош до Дића иде се узводно долином речице Драгобиљ, која протиче на стотинак метара од самог локалитета.

\section{Историјске околности}

Да би се добро разумео културно-историјски контекст у оквиру којег је настала Црква Светог Јована Крститеља са некрополом у Дићима, неопходно је сагледавање стања у пограничним областима српске средњовековне државе, у периоду од владавине краља Драгутина до коначног турског заузимања српске деспотовине. У време подизања цркве челника Вугдрага, овај локалитет у близини Рудника налазио се на простору краљевине Драгутина Немањића у XIII веку. Руднички крај био је важно средиште римског рударства (о чему сведочи храм Мајке Земље под Великим Штурцем), али своје трагове вуче још од праисторијског доба, о чему сведочи локалитет Прљуша - Мали Штурац. На том простору боравили су и Келти, у IV веку пре нове ере, а и Саси у XIII веку, који су дошли управо на позив краља Драгутина да обнове рударску делатност на Руднику. Захваљујући Сасима Рудник доживљава свој највећи процват. Од XIII до XVIII века на простору Рудника подигнуто је много сакралних објеката, а судећи по писаним изворима, претпоставља се да их има око осамдесет. Данас је очувано само пет манастира и четири парохијске цркве, а познато је и четрнаест рушевина, које су до данас необновљене (Челиковић 1962: 11).

Ова територија дуго је била под непрестаним притисцима са разних страна, и на њу су утицала и унутрашња и спољашња превирања. У време смрти челника Вугдрага, 1327. године, ова територија била је под великим променама и сменама краљева. Челник Вугдраг је засигурно умро за време владавине Стефана Дечанског, па ипак већину свог живота је морао провести под владавином Владислављевом или Драгутиновом. Поставља се питање од којег краља је добио своју титулу челника и на чијој је страни ратовао. На ова питања можемо одговорити посредно, бавећи се питањем 
његовог монашког живота. Да ли је било природно, пратећи узор српских владара који, након што престо оставе наследницима, приме монашку ризу, или насилно не би ли избегао погубљење? Постоји могућност да је учествовао на Владислављевој страни, те је након победе Стефана Дечанског био приморан да се замонаши заједно са својом породицом, као што видимо на примеру Николе Зојића. У том случају, имање му је било одузето.

Ужи простор Вугдрагове цркве припада средњовековној области око реке Љиг. Најстарији писани извор који говори о области на којој се овај простор налазио јесте повеља краља Жигмунда Луксембуршког 10. марта 1392. године. Наиме, у годинама након Косовске битке, Никола Горјански млађи држао је у свом поседу извесно Детошево поље, и понудио га је угарском краљу у замену за Кисег и Чесник. У њему је наведено да се састоји од три града и дванаест жупа (Гошњић $2019: 44)$. Детошево поље обухвата долину Колубаре и Љига, а самим тим и област на којој се налази црква челника Вугдрага. Помињање ове области јавља се и у даровници кнегиње Милице и њених синова Стефана и Вука 1395. године. Поред чланова породице кнеза Лазара који су дали прилог за манастир Русик на Светој Гори, нашао се и низ других властеоских приложника. Међу њима придружен је и логотет Лука, који је манастиру даривао цркву Матере Божије у Драгобиљи, „,ь сєАн н с мєтохомь н с мегтанн н правннамн црьквє тє що сї є дрьжалд прн дҺтошу" (Гошњић 2019: 47). Овај топоним можемо повезати са реком Драгобиљ, која се улива у Љиг, непосредно поред данашњег археолошког налазишта у Дићима.

У оба документа Детош се помиње као поседник ове области, али и као неко ко више није жив (или барем више не држи те области). Ко је наследио овај огромни властеоски посед и како је сам Детош до њега дошао, не зна се. Засигурно знамо једино да је посед припадао челнику Вугдрагу, властелину Детошу, затим Николи Горјанском у годинама након Косовске битке и логотету Луки. Недоумице око наслеђивања овог имања употпуњује чињеница да не постоји податак да ли је Детошевина била пронија или баштина. И једно и друго може доћи у обзир, јер се проније почињу спроводити управо након владавине краља Милутина. О хипотези по којој се могу повући извесне родбинске везе између Детоша и Вугдрага не можемо рећи ништа. Након упокојења челника Вугдрага, црква и поседи су засигурно били унутар породице још неко време, о чему сведочи богата ктиторска плоча и надгробни споменик који му подиже жена Владислава, као и постављање још пет надгробних плоча унутар цркве, где се сахрањује ктиторска породица. Детош је могао бити 
потомак челника Вугдрага или наследник његових области, уколико је његова област била баштина, али о томе нема никаквих података. Делује вероватније да је властелин Детош дошао до овог великог поседа пре Косовског боја, за време цара Душана, када је дошло до јачања властеле, јер је његов посед огроман, а велики поседи делили су се за време цара Душана, цара Уроша, и обласних господара. Коначно, након смрти цара Уроша отпочела је јагма око српског царства. Властелини су названи обласним господарима и једна од одлика њиховог јачања јесте њихово право да одузимају и додељују имања, независно од тога да ли је пронија или баштина, те та чињеница отежава доношење било каквог закључка о наслеђивању поседа челника Вугдрага, односно Детошевине. Предео око Рудника и сам Рудник заузео је обласни господар Никола Алтомановић 1366, док га кнез Лазар није поразио 1373. године. Детош је могао погинути у Косовском боју без наследника, а његова земља могла би бити и одузета од стране обласног господара и додељена неком другом, и да је његов посед била баштина, и да је имао наследника. Земља је свакако на крају пала у руке Николи Горјанском, зету кнеза Лазара. Са извесном сигурношћу можемо једино рећи да је Никола Горјански ово имање добио као мираз, те да свакако није био у крвном сродству са Детошем, нити са челником.

\section{Градитељство}

Властеоска црква Матере Божије у Дићима није усамљен случај. У долини Љига проналазимо још средњовековних цркава са властелинским ктиторством, из друге половине XIV века или прве половине XV века: у Славковици, Бау, Моравцима, Ћелијама и Боговађи (Гошњић 2019: 58). Црква у Дићима припада рашком стилу. Једноставног је облика и састоји се од наоса, олтара са апсидом и припратом. Олтар заузима највећи део, док средишњи травеј нема потребе за великим простором, пошто је предвиђена за мали број верника, односно осмишљена више као крипта, те је њен ктитор морао бити властелин који је држао посед у долини Љига. Не знамо можемо ли говорити о манастиру, јер нису пронађени темељи зграда и ћелија, те се и даље поставља питања где је живео челник Вугдраг током свог монашког живота. Темељи цркве у Боговађи и Моравцима још увек нису откривени, услед рушења и надограђивања, међутим, слична архитектоника првобитних темеља може се очекивати. У Бау и Ћелијама такође су извршене промене. Најсличнија јој је црква у Славковици. Постоји још једна сличност коју деле Славковица и Дићи, а 
то је постојање некрополе, састављене од лежећих надгробних споменика око цркве. Надгробни споменици су тако збијени и сасвим окружују цркву, што сведочи о појави масовног сахрањивања око цркве која није у употреби. У Боговађи, Бау и Моравцима не затичемо такво стање, услед тога што су цркве одржане до данашњих дана.

\section{Некропола}

Некропола у Дићима је највећа средњовековна некропола у Србији и броји тренутно сто осамдесет надгробних плоча. Осим водоравних плоча и слемењака, налазимо усправне плоче, крстаче, и стубове капичаре. Плоча̂ са симболима има четрдесет. Некропола припада западносрбијанској групи, низу веома сличних некропола западно од Колубаре, а источно од Дрине, као и око Пожеге. Како је црква морала бити подигнута пре 1327. године, некропола око цркве је морала настати након подизања цркве, али и након њеног гашења. Близина гробова цркви, који је потпуно окружују и онемогућавају јој приступ, сведочи томе да црква није била у употреби. Оно је окупљено око развалине ове цркве, страдале у турским освајањима, која је највероватније и пре тога опустела. Заснивање гробаља око сакралних грађевина није необичан и усамљен случај, већ средњевековна пракса. Гробље је настало у XIV веку, што се слаже са археолошким открићем новчића из периода цара Уроша, а са сигурношћу се може датирати у XV и XVI век.

Ради лакшег сналажења, извршићемо грубо датовање разних врста споменика, полазећи од искуства радова на истраженим некрополама, уз помоћ књиге Николе Дудића. Водоравне плоче и слемењаци оријентисани су у правцу запад-исток, као и црква око које су густо збијени. Тако долазимо до закључка да су то најстарији надгробници. Рас, Кончулиће, Градац, Сопоћани, Дежево јесу локалитети на којима се јављају водоравне плоче. Најзаступљеније су у Западној Србији, Сјеничкој висоравни и областима западно од Новог Пазара. Водоравне плоче око цркава Светог Николе у Брвенику и Славковице датиране су у XIV век. Њима припада и гробље у Дићима. Треба нагласити и водоравне плоче са слеменим ребром, као у Јаначком пољу из XIV века, и у Шароњи из прве половине $\mathrm{XV}$ века. Такве исте постоје у виду поклопца на саркофагу у Славковици, али и на гробљу у Дићима.

На југозападу гробља увиђамо усправне плоче, плоче са испупченим врхом, плоче са рустичним крстовима, крстаче, и они су „друга генерација” надгробника. Удаљеност усправних плоча од цркве говори и о временској 
дистанци између њих. Они су на овом гробљу морали настати након водоравних плоча и слемењака, премда се питање хронологије усправних и водоравних плоча може с правом поставити, пошто се некада њихово датирање преплиће. Ближе југу гробља наилазимо на капичаре, а онда и на новије надгробне плоче које са сигурношћу можемо датовати у XIX, XX и XXI век на основу уписане године. Стубови из Драгачева који су јако накићени и потичу из XVIII и XIXвека, веома подсећају на капичаре из Дића.

О сличности дићких слемењака са стећцима сведоче симболи: крст, круг, спирала, али и слемено ребро, што закључујемо уз помоћ Бешлагићеве књиге о стећцима. На водоравним плочама у Дићима јавља се астрални мотив круга, односно Сунца, биљни мотиви стабла - дрвета живота, спирале, розете, крина као и представе човека - његова фигура и полуфигура и штап. Представе покојника настале су у пластици и урезу и најчешће су приказивале опружено тело, глава с рукама прекрштеним на грудима, а свој коначни облик проналазе у фотографији која се на модерним надгробницима налази и данас. Од крстова појављују се грчки, латински, калваријски, антропоморфни и свастика. На слемењацима налази се ребро, које се може проширивати у круг, и постоје одређене варијације на исту тему. На плочама са рустичним крстовима налазе се представе човека, а на усправним плочама представе човека као и процесијски, калваријски, лоренски и антропоморфни крст. На усправним плочама XIX века јављају се и симболи занимања: наковањ и чекић, а на многима се јавља и преслица што означава женску полну припадност. На стубовима драгачевског типа, капичарима, јавља се фигура човека са мотивом акантуса-палмете на чијем се врху налази птица, или понекад анђео, на бочним странама споменика. Од мотива најинтересантнији је мотив три геометријска тела: један круг и два квадрата, око којих су зракасто распоређене линије. Сличан мотив налази се и у Славковици. У српским предањима познат је мотив три сунца, које једе змија, о чему говори Софија Костић у Култу змије код Срба. Уколико се заиста може направити веза између ове представе и народне бајке, онда се надгробној симболици могу приписати и особине фолклора заснованог на паганским мотивима.

У дићкој некрополи заступљени су сви типови споменика сем ковчега и саркофага, а од камења коришћен је најпре ингибрит, пешчар (меки или тврди), мермер, кречњак, сига, а најређе гранит. Запажамо употребу шестара. 


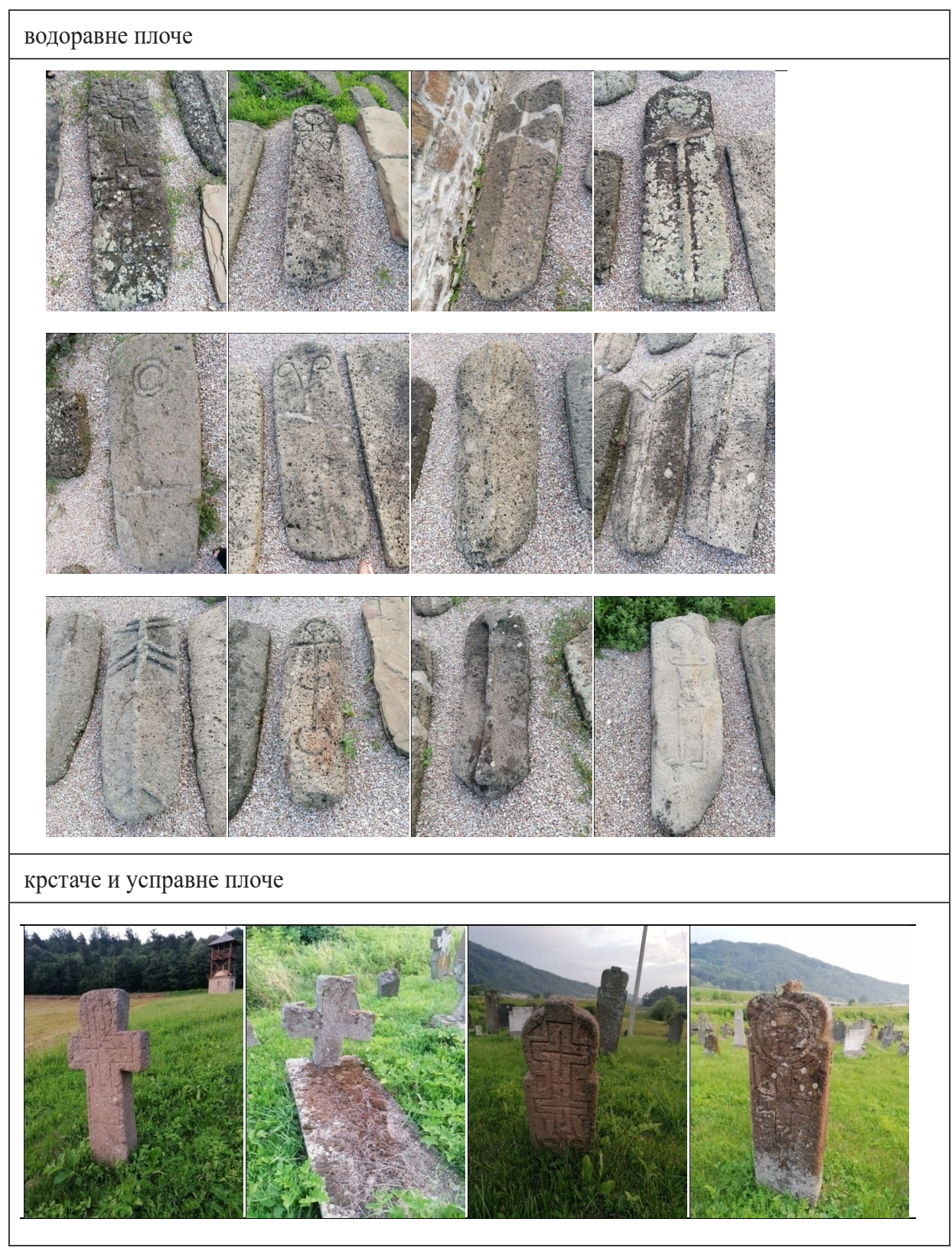




\section{Натпис на надгробној плочи}

У наосу цркве пронађено је шест надгробних плоча. Пет су од мермера, док је шеста од пешчара. На четири су пронађени натписи, од којих је читљив једино онај на надгробној плочи челника Вугдрага. Она је дводелна и на другој половини налази се представа три розете; док је на другој плочи, такође дводелној, представа крина и розете. Натпис на ктиторско-надгробној плочи исписан је у тринаест редова, док је величина слова четири центиметра.

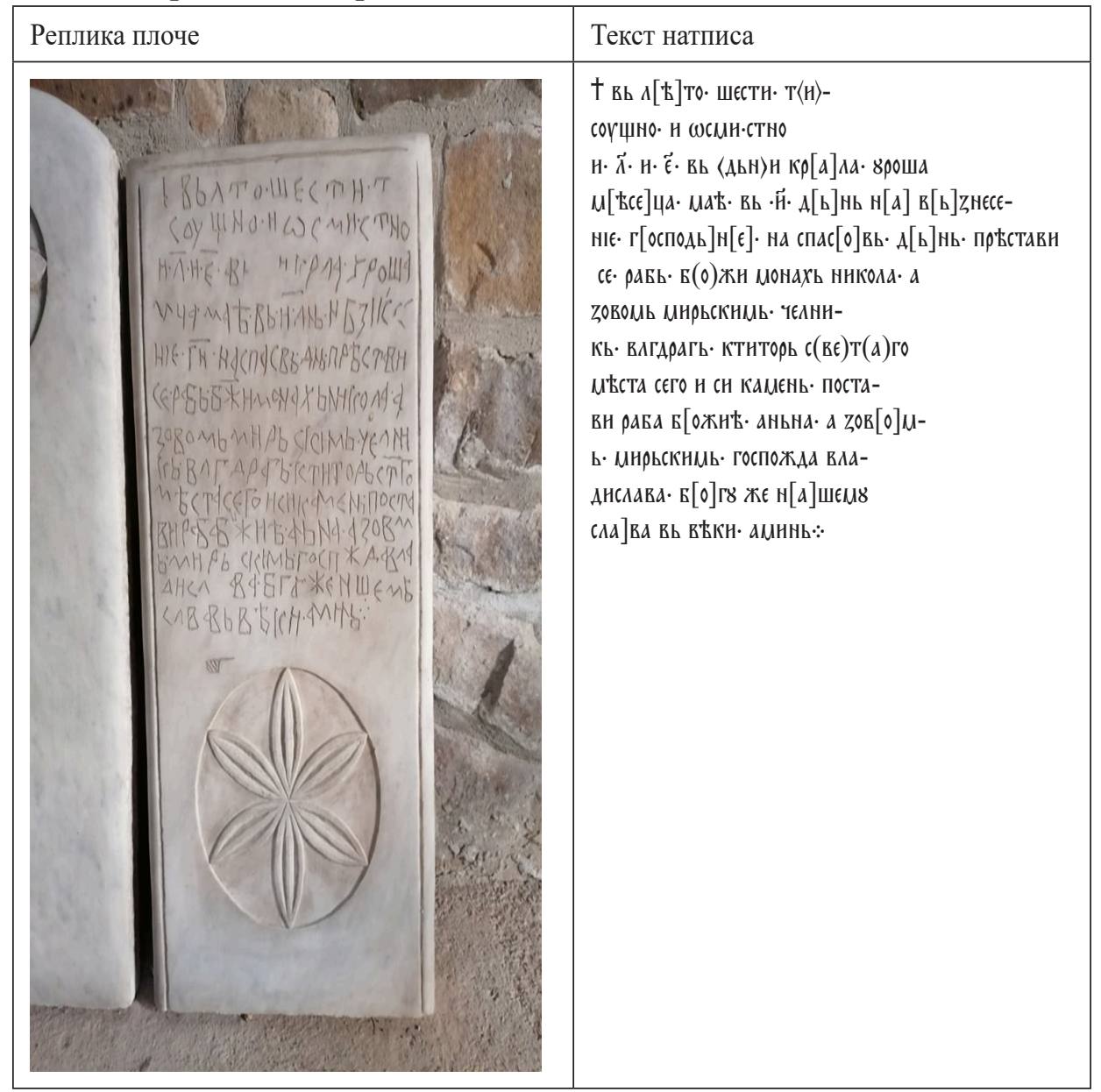




\begin{tabular}{|l|l|}
\hline \multicolumn{1}{|c|}{ Транскрипција: } & \multicolumn{1}{|c|}{ Пренос на савремени српски језик: } \\
\hline Ва лето шести тисуштно и осми стотно & У лето шест хиљада и осам стотина и триде- \\
и тридесет и пето, ва дни краља Уроша, & сет и пете, у дане краља Уроша, месеца маја, у \\
месеца маја, ва осми дан, на Вазнесе- & осми дан, на Вазнесење Господње, на Спасов- \\
није Господње, на Спасовдан, преста- & дан, престави се раб Божји монах Никола, а \\
ви се раб Божји монах Никола, а зовом & зван световним (именом) челник Вугдраг, кти- \\
мирским челник Влгдраг, ктитор света- & тор светога места овог; и овај камен постави \\
го места сего, и си камен постави раба & раба Божија Ана, звана световним (именом) \\
Божија Ана, зовом мирским госпожда & госпођа Владислава. Богу пак нашем слава у \\
Владислава. Богу же нашему слава ва & векове, амин. \\
веки, амин. & \\
\hline
\end{tabular}

\section{Језичке одлике натписа}

Служећи се Историјом српске ћирилище Петра Ђорђића, као и Кратком историјом српског књижевног језика Александра Милановића, анализираћемо овај натпис. Судбина гласовне вредности јера у српскословенском била је двојака: или се вокализовао у јаком положају или се изгубио у слабом. То важи за све случајеве осим код самогласничких $p$ и л, када полугласник има улогу обележавања вокалности ових латерала, независно од јаког или слабог положаја. У споменицима у којима се полугласник не бележи у слабом положају не бележи се ни уз вокално $p$ и л, као што је случај на овом споменику. Вокално $л$ у речи ВАгдрагь је прасловенског порекла, које је у народним говорима крајем XIII века дало $y$. У тој речи срећемо и једначење по звучности, што је одступање од етимолошког правописа и приближавање народном језику.

Наставак -нїє јесте чест именички завршетак, где слово н задржава своју гласовну вредност, као у речи в[ь]zнєєенєє. То су глаголске именице књишког порекла, које такође сведоче о старословенској традицији (у народном језику се захваљујући новом јотовању говорило вазнесење, али ту црту не срећемо на овом споменику).

На плочи челника Вугдрага срећемо јат које обележава групу ја иза

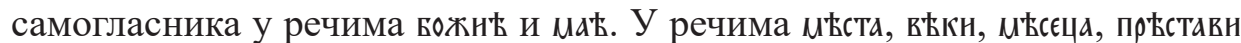
$c \epsilon$, เ $\mathrm{k} т$ јатом се обележава $e$. Међутим, јат се не пише иза палаталних, већ се група $s a$ обележава са ла, што видимо у речи крала, а група $ь a$ обележава се са $н a$, што видимо у речи господна, што представља одвајање од старословенске традиције и приближавање српскословенској. Судећи по одсуству лигатура за прејотоване вокале које преовладавају још у XIII веку, можемо рећи да овај натпис припада зетско-хумском, односно старијем рашком правопису. 
Што се тиче гласова $\hbar$ и $\hbar$, на овом споменику нису искоришћена српскословенска решења (ђерв у зетско-хумском и 2 и $\kappa$ у рашком правопису), већ старословенске гласовне групе $и т$ и жд. Лигатура щ и група жА јесу књишки облици наслеђени из старословенског, и представљају решења за гласове $\hbar$ и ђ у народном језику, и то видимо у речима тнсоүщн, госпожАа.

Слова у значењу бројева употребљена су правилно, са титлом у облику црте изнад слова и са тачкама између њих. Извршено је датирање уз помоћ византијског рачунања времена. Осим године помиње се и месец и дан, као и празник на који је челник умро. За месец је искоришћен латински назив. Тачке не само што раздвајају реченичне делове, него раздвајају и саме речи. Употреба лигатура најчешћа је у спојевима ав и $а$. Овом споменику својствена је и експресивност израза, што је превасходно одлика ктирорских а слабије само надгробних споменика. У епиграфији експресији доприносе акузативне синтагме са устаљеном формулом. Овде је акузативна са допуном у генитиву, којом је изражено време збивања и које су карактеристичне за ктиторске натписе: „Вь днн...” (Чигоја 2008: 20).

Овај натпис, дакле, одликују следеће особине:

- $\quad$ писање јата уместо лигатуре г, писање група ла и на за ља и ғь $а$ (зетско-хумски правопис);

- п писање ч и жд уместо ђерва, писање именица књишког порекла, одсуство примера вокализације слабог полугласника (старословенска решења);

- $\quad$ присуство лигатура (рашки правопис);

- $\quad$ недостатак лигатура за прејотоване вокале (глагољска традиција);

- $\quad$ писање самогласничког $л$, одсуство новог јотовања (непродирање народних фонетских црта).

Оваква архаичност својствена је епиграфији и доприноси монументалности израза. Према изгледу слова можемо закључити да су увелико коришћена старија решења и варијанте. У складу са особинама зетско-хумског (са примесама рашког) правописа и чувањем књишке, старословенске традиције, можемо рећи да је наручилац текста неговао старину српског писма и ортографије и да је користио традиционална ортографска решења уместо својевремених и очекиваних за XIV век. То је у епиграфији честа појава и показује заостајање у односу на рукописну праксу неговану на хартији и пергаменту, при чему се брже прихватају правописне новине. 


\section{ЛИТЕРАТУРА}

Белић 1999: А. Белић, Историја српског језика: студије, расправе, критике, Београд: Завод за уџбенике и наставна средства.

Бешлагић 1982: Ш. Бешлагић, Стећии - култура и уметност, Сарајево: Веселин Маслеша.

Гошњић 2019: В. Гошњић, Олтар Светог Георгија при реци Љигу 1, Београд: Дучић.

Грицкат 2004: И. Грицкат, Студије из историје српскохрватског језика, Београд: Завод за уџбенике и наставна средства.

Дудић 1995: Н. Дудић, Стара гробља и надгробни белези у Србији, Београд: Просвета.

Ђорђић 1990: П. Ђорђић, Историја српске ћирилице: палеографско - филолошки прилози, Београд: Завод за уџбенике и наставна средства.

Јеж 2001: Ж. Јеж. „Некропола Дићи, прилог познавању средњовековних надгробних споменика", Саопштењ а XXXII-XXXIII / 2000-2001, Београд 135-145.

Милановић 2010: А. Милановић, Кратка историја српског књижевног језика, Београд: Завод за уџбенике.

Срејовић и др. 2000: Д. Срејовић, Историја Срба, Београд: Српска књижевна задруга.

Томовић 1974: Г. Томовић, „Морфологија ћириличких натписа на Балкану”, Београд: Историјски институт.

Томовић 2009: Г. Томовић, „Посед српског властелина Детоша у XIV веку", Историјски часопис, књига LVIII, Београд, 93-107.

Ћирковић 1997: С. Ћирковић, Срби у средњем веку, Београд: Идеа.

Ћоровић 2006: В. Ћоровић, Илустрована историја Срба, Београд: Алнари.

Чајкановић 1994: В. Чајкановић, Стара српска религија и митологија, Београд: Српска књижевна задруга.

Чајкановић 2014: В. Чајкановић, Из српске религије, митологије и фолклора: изабране студије, Београд: Евро-Ђунти.

Челиковић 1962: Б. Челиковић, Светилишта рудничког краја, Крагујевац: Каленић.

Чигоја 2008: Б. Чигоја, Најстарији српски ћирилски натписи, Београд: Чигоја. 
Nastasija Z. Perić

\section{INSCRIPTIONS ON THE FOUNDER'S TOMBSTONE IN THE CHURCH OF SAINT JOHN THE BAPTIST IN DIĆI}

\section{Summary}

This paper deals with the analysis of the inscription on the chelnik Vugdrag's founder's tombstone in the $14^{\text {th }}$ century church, in the village named Dići. With the help of the letter analysis and orthography we will discover certain characteristics of the inscription carved in stone. The inscription will be localized in space and time and put in historical context which will help open certain questions and hypothesis connected to chelnik Vugdrag's life and death

Key words: necropolis, Vugdrag, church, Rudnik, letter, gravestone, $14^{\text {th }}$ century. 